\title{
The institution of consumer instalment sales credit and its relationship to cyclical fluctuations
}

\author{
W.N. Meyer \\ Department of Economics, University of Port Elizabeth
}

\begin{abstract}
The contribution of consumer instalment sales credit (hire pur. chase credit) to fluctuations in economic activity is the source of some conflict between two diverse viewpoints. On the one side there are those who use a Keynesian analysis to argue that an increasing volume of consumer instalment sales credit has an accelerating effect on the expansion of effective demand far out of proportion to its own relative size and that a subsequent retardation in consumer instaiment extensions will cause a more rapid acceleration in the contraction phase of the cycle. The results, respectively, would be a higher peak to a boom and a deeper recession. On the other hand, some writers, while not refuting the Keynesian analysis, feel that, although consumer hire purchase credit's influence on cyclical fluctuations merits careful study, its possible destabilizing effect is not so significant as to overshadow all its desirable aspects. They argue that the cyclical behaviour is questionable and cannot be isolated from other elements of the economy. This article will analyse and evaluate some of the existing theories to discover their weaknesses and strong points.

S. Afr. J. Bus. Mgmt 1980, 11: $141-147$
\end{abstract}

Die bydrae van verbrulkershuurkoopkrediet tot fluktuasies in ekonomiese aktiwiteit is die bron van konflik tussen twee uiteenlopende gesigspunte. Aan die eenkant is daar die wat deur die toepassing van 'n Keynesiaanse analise argumenteer dat 'n toenemende volume van verbruikershuurkoopkrediet ' $n$ versnellende effek op die uitbreiding van effektiewe aanvraag het buite verhouding tot sy eie relatiewe grootte, en dat 'n daaropvolgende afname in verbruikershuurkoopkrediet ' $n$ vinniger versnelling in die kontraksiefase van die siklus sal veroorsaak. Die gevolge is, onderskeidelik, 'n hoor piek in die oplewing en 'n daaropvolgende dieper depressie. Aan die ander kant is sommige skrywers, terwyl hulle nie die Keynesiaanse analise verwerp nie, van mening dat, hoewel verbruikershuurkoopkrediet se invloed op sikliese fluktuasies deeglike studie regverdig, die moontlike onbestendige effek daarvan nie so beduidend is dat dit al die gunstige aspekte daarvan oorskadu nie. Hulle argument is dat sikliese gedrag bevraagteken kan word en nie van ander elemente van die ekonomie geskei kan word nie. Hierdie artikel analiseer en evalueer sommige van die bestaande teoriee om hulle swakhede en goeie eienskappe vit te lig.

S.Afr. Tydskr. Bedryfsl. 1980, 11: 141-147

W.N. Meyer

Department of Economics, University of Port Elizabeth,

P.O. Box 1600, Port Elizabeth 6000
Payments for the use of another's funds to finance personal expenditures can be documented in records of the ancient as well as the medieval world. Money lending was generally viewed with disfavour, but since most loan requirements were for consumption purposes due to personal misfortunes or emergencies, it was allowed, subject to the restrictions of religious or ethical standards of the society. Loans to finance overseas commerce were also countenanced, and the surrounding facts seem to indicate some recognition in that day of the distinction between productive and consumptive credit.

In the middle ages efforts continued to suppress the taking of interest, while those in need of funds and those with money to lend looked for means of circumventing the restrictions. The church allowed certain exceptions for actual losses which the lender sustained as a result of not having the use of his money (damnum emergens). Eventually, exceptions were made to provide payment for the theoretical profits he might have made (lucrum cessans). The disfavour with which loans for consumption purposes have been and sometimes still are viewed thus have its origin in antiquity, but we have adapted our thinking to newer economic concepts or become sufficiently well versed in rationalization to almost completely overcome this legacy.

Just when the first retail salesman said to a hesitant customer 'Buy now and pay later', is not known, ' but it is sufficient for our purposes to realize that the distinction between producer and consumer credit became completely clear when production was removed from the household by the industrial revolution, and the factory system took over that large segment of our economy. ${ }^{2, p 42}$ Instalment buying and selling, known variously and sometimes inaccurately as 'deferred payments', 'time sales', 'easy payments', and 'instalment plan' (in the USA); and as 'hire purchase' or the more picturesque 'never-never' in England; 'vente à tempérament' or 'vente à crédit' in France, has developed in South Africa from roots that extend back to the end of the 19th century. It seems that the American Singer Company sold sewing machines on the instalment plan in Cape Town as early as the 1890 s. However, the introduction of instalment sales credit to South Africa came rather late if compared to Europe and North America.

Evidently, the first formal agreement to hire with an option to purchase was concluded in 1821 . The invention of the sewing machine about the middle of the 19th cen- 
tury provided an opportunity to launch the method of hire purchase, and the Singer Company set a pattern which was soon to be followed by the suppliers of pianos, furniture and other household equipment. ${ }^{3 . p p} 20-22$ In South Africa the field of durable goods which could be sold on hire purchase before 1920 was limited in extent and the system only expanded prodigiously when motor cars and, later, electrical appliances came into common use. $^{4}$

Although credit at this stage was primarily mercantile and in any event was not granted indiscriminately, certain economic conditions gave rise to the use of retail credit especially to facilitate the purchase of relatively highpriced merchandise. The credit instrument was usually a promissory note in the amount of the balance remaining after a downpayment or deposit. The note would be payable at a specified time, usually in 60 or 90 days.

The use of open-book credit was also greatly in evidence in the early part of this century. Wage earners were required to settle after each payday; business and professional people made monthly settlements, while farmers were usually financed from one crop to another.

The late growth of the hire purchase system in South Africa - at least a quarter of a century after it had come into prominence in Europe and North America - can be attributed to the strong personal factor in the debtorcreditor relationship in the retail trade. Especially farmers took an aversion to signing a hire purchase agreement as this would have been regarded as a clear token of distrust. ${ }^{4}$ pp $25-26$ However, once hire purchase credit was accepted by dealers as a means of promoting sales, and by consumers as a facility which enabled them to acquire durable goods without taxing excessively their current incomes or small savings, the system entered a period of swift development.

One definition of consumer instalment sales credit stipulates, first, that it is credit used for consumption purposes; second, that the payments are in regular amounts on a prearranged schedule; third, a financing charge is made; fourth, it is short or intermediate in nature; and fifth, it is attested by a negotiable instrument providing for legal action in case of default on repayment. ${ }^{5, p} 18$ In another statement the system is defined as a transfer of wealth, the payment for which is deferred in whole or in part to the future. ${ }^{6, p 2}$

The early differentiation between instalment (i.e hire purchase) and open-book credit, was that the former is granted specifically in conjunction with a single purchase, usually of a consumer's durable, but the initial amount of credit was much larger. Payments were individually smaller since the repayment was spread over a longer period. Lastly, a partial cash payment was usually required at the time the purchase was made. ${ }^{2 . p}{ }^{54}$ The Hire Purchase Act of 1965 also stipulated that hire purchase is a contract of purchase and sale whereby the right of ownership is transferred on delivery of the good.

Some further qualifying observations should be made. At times transactions considered to be in the category of consumer instalment credit may be put to use partially or wholly for business purposes. A motor car, for example, may be used by a salesman in the conduct of his business and also for family pleasure. Secondly, although openbook accounts are not included in the instalment credit classification, it should be noted that present-day, socalled revolving charge accounts are a compromise arrangement embodying characteristics of both open-book and instalment credit. The period of time for repayment of hire purchase credit is longer than that usually allowed for the settlement of open-book accounts, however. On the other hand, residential mortgages are not included in the definition because their time element is far beyond that of instalment credit.

\section{Early instalment sales}

Consumer instalment sales credit in South Africa appears to have originated in Cape Town before the first world war in the sewing machine and furniture trade. The use soon spread to other similar businesses and to other large towns. Manufacturers of goods like motor cars, industrial appliances, lifestock, books, musical instruments, encyclopaedias and 'soft wares' soon also entered the field of hire purchase credit. Since this type of business, in contrast to that of the furniture houses, was carried on largely by itinerant agents, the spread of the idea of instalment selling from one community to another was fostered by their resulting geographical and financial progress. ${ }^{2, p}$ 67 Thus, hire purchase trading developed rapidly in the fields of furniture and motor cars. The great popularity which the motor car began to enjoy was, no doubt, the strongest single factor favouring hire purchase selling in the 'twenties.' ${ }^{75}$ By far the most goods that were sold on hire purchase was merchandise of good quality and of high utility to the purchaser. Credit was extended to him as a service and did not always influence his decision to buy. He usually had an established reputation which indicated that he was a good credit risk.

The Great Depression interrupted the growth of hire purchase and on the whole, the volume of financing business done was not very great. However, during the period 1933-1939 registration of motor cars increased from 150000 to 320000 ; hire purchase finance was a powerful factor in this expansion. In a memorandum submitted by the Motor Trade Association to the Select Committee on the Hire Purchase Bill of 1939, the ratio of hire purchase to total sales of motor vehicles was estimated at no less than $80 \% .^{7, p} 6$

\section{Renewed expansion after World War II}

Hire purchase entered its post-World War II phase of expansion in 1947. By this time the use of instalment credit was extended to the lower-income classes, who were generally poorer credit risks. Black and coloured people, however, were predominantly the victims of artful salesmen who induced them to sign a hire purchase contract which, in many cases, they could not hope to meet. Although a small percentage of the total hire purchase business, this brought some measure of disrepute upon the whole field of instalment selling. Thus, a new market factor had become a fact: the Hire Purchase Act of 1942 (Act No. 36). The Act made provisions mainly for the prevention of the exploitation of wealth by the stronger economic class at the expense of the weaker classes of the community.

Therefore, legislation was introduced with a view to retain the better part of the hire purchase system - as it unquestionably contributes to an increase in the standard of 
living of the less-wealthy population - and to prevent abuse. ${ }^{4, p p ~ 34-35}$ The Act made an important provision so as to fix the minimum deposit at one-tenth of the purchase price and eliminated the sales of furniture and domestic appliances which were effected at a less than $10 \%$ deposit basis before the war. This, however, hardly affected the strong growth of the hire purchase system in the post-war years. The total amount outstanding in respect of instalment sales of durable consumer goods and motor cars (excluding commercial vehicles) at the end of 1954 was estimated at R62 million. ${ }^{4, p} 20$

This development phase was characterized not only by the growth of the volume of consumer goods sold on hire purchase but also by the extension of hire purchase (and leasing) to the commercial and industrial spheres. This widening of the use made of hire purchase, which had already begun in a modest way before the war, was made possible by the existence of an efficient system of hire purchase financing, which had grown up during the preceding 25 years.

It is not surprising that in view of the growth in instalment sales credit in general the government tried to gain control over hire purchase credit extended to consumers in particular. The Hire Purchase Act of 1942 was replaced by the Hire Purchase Act of 1954 which gave the Minister of Economic Affairs the power to vary the hire purchase terms. Except for a minimum deposit of $10 \%$, however, no restrictions were in force until October 1955, when the minimum deposit for motor cars was determined at $45 \%$, and the maximum credit period at 18 months. ${ }^{4} p 9$ Owing to the similarity of open-instalment credit to hire purchase credit, the scope of the Hire Purchase Act was widened in 1965 by an amendment to the Act, the effect of which was to include some of these open-account transactions as well. ${ }^{8,}$ p 5

After the announcement of more severe hire purchase terms, also in terms of the Price Control Act of 1964, some traders resorted to the practice of leasing motor vehicles to the public by means of so-called leasing contracts which are really nothing but sales contracts, the object being to evade the prescribed terms in respect of motor vehicles. The Committee of Inquiry into the Usury Act, therefore, was of the opinion that this type of quasisales contracts had indeed to be covered by the legislation recommended by them. ${ }^{8, p 16}$ Since then the Minister of Economic Affairs has been taking measures to control the extension of hire purchase credit so as to stimulate or dampen the demand for consumers' durables as economic conditions demand. This has been done mainly through the determination of stricter hire purchase terms since the consumers' demand for durable goods appears to be interest inelastic. ${ }^{\text {s. } p p^{100-101}}$ This situation makes it possible for a seller to mislead the public by quoting relatively low prices, only to collect a large amount in finance charges once the buyer decides on the basis of the low price quoted to buy a particular article. The result was that the disclosure of finance charge rates has been made compulsory in South Africa. ${ }^{8, ~ p 21}$

The reason given for the stricter terms on hire purchase lending instituted in October 1970 was, for example, 'that both consumer spending and prices are presently increasing at rates which endanger the country's economic stability, while on the other hand the level of savings leaves much to be desired. The substantial rate of spending in the Republic is also reflected in the very high level of imports which exerts considerable pressure on the balance of payments. Expenditure on durable consumer goods in particular has assumed excessive proportions, and many of these goods have a large import content'.?

In a comment to this by the Association of Chambers of Commerce it is stated: 'The Association recognizes the effect that hire purchase controls could have on consumer durable spending, but regards them as ill-qualified for use as a major instrument of policy because they concentrate their attack on the consumer durable industries which are to a notable extent a spear-head of economic progress. These are industries in which forward planning of production, steady runs, maximum use of plant and equipment and expanding volume are all of the greatest importance for efficient development ... . Hire purchase controls used for anti-inflationary purposes affect a relatively small proportion of total spending on goods, let alone services. Even in the field they do affect, they tend to curtail spending only in certain income groups'. ${ }^{10}$

Shortly afterwards the responsible minister again eased the hire purchase terms 'after careful consideration of the representations received from certain manufacturers'."

Considering the important role played by the durable goods industry (in South Africa, consumers' 'investments' in durable goods and houses amounted to more than R3 000 million in 1977, nearly as important as total gross investments by private business of $R 3743$ million and more important than investments made by public authorities of R2 950 million in the same year ${ }^{12}$ ), particularly the motor industry, in the South African economy, it may be of interest to make a brief excursion into some of the existing theories pertaining to the economics of instalment buying. An attempt thereto is undertaken in the following sections.

\section{Economic theory of consumer instalment sales credit}

The rapid growth of consumer instalment sales credit (hire purchase credit) and the realization of its economic significance began to attract more attention from economic writers around the middle of the 1920s. Generally, assuming the classical position of full employment, it was argued under Say's law that an expansion of consumer credit could expand the production of consumer goods only at the expense of the producers' goods industries, and a contraction of consumer credit would result only in a shift of productive factors back to the producers' goods industries. Under 19th century conditions of growing demand in an economy working close to its present capacity these assumptions offered a reasonable basis for a first approximation of the situation. The resulting conclusion of the exponents of the aforesaid doctrine was that the expansion of consumer credit would influence the growth of the economy adversely, in the long run, by retarding the movement of capital into production.

The contention of some that consumer credit has filled the gap between production and purchasing power, represented an attack on Say's law, but the attack on the classical position was not pursued to disclose its fundamental weakness. It was contended that to maintain 
the equilibrium between production and consumption necessitated an increasing rate of expansion of consumer credit. Such an expansion, it was felt, could not continue indefinitely and a depression would result. ${ }^{2 . p}$ 167 $^{16}$ was predicted that the credit capacity of the public would eventually become saturated, and total purchasing power would diminish, leaving the artificially expanded productive capacity of affected industries unused..$^{2 . p}{ }^{166}$ Mill had stated that: 'Credit given by dealers to unproductive consumers is never an addition, but always a determent to the sources of public wealth. It makes over in temporary use, not the capital of the unproductive classes to the productive, but that of the productive to the unproductive'. 2. p 1s1

A later observation does not completely refute Mill's view, but merely questions some of his underlying assumptions as not being appropriate to the economy of this century. ${ }^{2 . p} \mathrm{p}^{168}$ Essentially it is felt that consumer hire purchase credit can contribute to increased production as a result of labour-saving characteristics of the durable goods, and generally that expansion of consumer credit does not necessarily detract from the accumulation of productive resources.

Another view refutes the contention that the laboursaving features of durable consumer goods allow any large amount of consumers' labour to be added to the exchange system, contending that the bulk of the energy so released results in increased leisure rather than in more labour entering the exchange system. ${ }^{13, p}{ }^{47}$ The legitimacy of the claim of increased production, however, may be seen clearly today in the shift from the use of commercial laundries' services, especially by the middle income group, since automatic washers and dryers have taken the drudgery out of home laundry. Many housewives who would not use a scrubbing board or even a wringer washer, because of the menial nature of the task, do not mind expending the necessary additional effort to do their own laundry with automatic equipment, instead of sending it out. Thus, additional labour, formerly leisure, has been added to the system replacing the labour of the laundry worker which is then available to be applied elsewhere. The same reasoning may be seen to apply to other similarly affected industries, such as bakeries and public transportation, as well as to the use of domestic servants in the home. And, where increased leisure has resulted, more labour has been employed by industry and service operations connected with leisure-time activities.

Only because the family has the opportunity to purchase vacuum cleaners, waxers, cake mixers, and motor cars, as well as automatic washers and dryers, by means of hire purchase credit - and at an early stage in its life cycle - is it possible for the additional labour to be fully utilized. Without consumer instalment sales credit this additional labour would be lost to the family and the economy, not only during the period of instalment payings (assuming the family would save voluntarily as much as the principle repayment each pay period) but, if they maintained their standard of living in the meantime, for an even longer period. They would continue to send out laundry, buy bakery goods to a greater extent, have a cleaning servant in more often, and use public transportation more extensively than if they owned the durables. Since the excess costs of these durables would be deducted from the savings toward the purchases of the durable goods, the period would be prolonged and the goal often not achieved completely.

In contrast to those who saw the stimulating effects of this credit in an expansion merely offset by the depressing effects in the contraction, ${ }^{2, p} 166$ others adhered to the view that the increase in purchasing power afforded by consumer instalment sales credit causes a rise in production which augments future consumer income and purchasing power so that the additional income generated is at least equal to the amount of the obligation. Although the finance charges represent an additional cost to the instalment buyers, they are payment for services and also become part of the national income. 'Instalment credit, in other words, does not simply advance purchasing power; it may augment purchasing power' 2. p 167

Those taking this position, while denying the classical assumption, had not thought the problem through, for they apparently did not comtemplate the possibility that the process of increasing production and purchasing power as the result of the credit expansion might be reversed by its contraction. ${ }^{2, p} 169$

Some observed cautiously that consumer instalment sales credit may be seen to lend aid to ef fective demand for goods of a growing industry and thus increase production and purchasing power in a spotty manner. ${ }^{2, p} 168$ The lack of conclusiveness in dissenting from the classical position may be attributed to the lack of definiteness in dynamic economic theory of that period. Until the acceptance of the condition that an equilibrium position of incomplete utilization of the factors of production might exist, as developed by Keynes, ${ }^{14}$ the deviations from classical theory, recognized by many, remained unresolved.

\section{The theory of Nugent and Haberler}

\section{Nugent's explanation}

Nugent's work, coming close on the heels of the General Theory, uses an almost completely Keynesian analysis to show the effect of consumer instalment sales credit fluctuations on the economy. He is concerned, however, that a use of the 'savings equals investment' keystone of Keynes' theory may be misconstrued, and so he employs the term 'investment' in the popular sense to refer to intentional expenditures which result in capital formation, and 'savings' to refer to intentional savings by income recipients. ${ }^{2}$, pp $171-172$ Having confined his concept of saving to 'depressing withdrawals' and investment to 'stimulating outlays', he thus is able to say that the differences between saving and investment result in changes in income and to sidestep the 'ex post-ex ante' issue.

If, according to this definition, investment exceeds savings, a primary addition to the income stream equal to the difference between the two immediately takes place, providing idle balances are available for the additional expenditures. Although prices will tend to rise, the rise will be limited by the existence of idle productive factors. ${ }^{14, \text { p } 296}$

The enhanced profit picture, together with declining inventories, will induce entrepreneurs to increase output and employment. Thereupon a secondary effect will be set in motion, since increased effective demand will result from that portion of the incremental income which is 
consumed. The total of all such successive increments is, of course, the multiplier effect, and its extent accordingly is based on the marginal propensity to consume (MPC).

In Nugent's terminology the secondary effect is the multiplier minus one (the primary effect) times the excess of investment over saving - less leakages - or: $(k-1)$ $(I-S)$. Since $k=\frac{1}{1-M P C}$, for an MPC of $\frac{3}{4}$ for example, the secondary effect would be: $\left(\frac{1}{1-\frac{3}{4}}-1\right)$ times the excess investment, or: secondary effect $=3 \times$ (excess investment).

A tertiary effect is the induced investment resulting from the familiar acceleration principle due to the increased demand.

A contraction of effective demand, i.e. a reversal of the primary, secondary and tertiary effects described above, occurs if, due to an excess of savings over investment a reduction of credit takes place. Primarily, the excess of saving means a reduction in the income stream and a corresponding reduction in consumption. Secondarily, the multiplier effect, less the primary effect, takes place. The multiplier in this case is based on the MPC of the decrement. A tertiary contraction of investment, as a result of the reduction in effective demand for consumer goods produced by the affected capital goods, completes the contraction phase.

Nugent carefully develops the concept of expanding consumer instalment sales credit as a source of 'incomeincreasing outlay', contending that credit-based expenditures, whether made by producers or consumers, must be capitalized in order to have the stimulating effect described. ${ }^{2, p}{ }^{177}$ It can be argued that the method of accounting does not alter the effect of the added investment, ${ }^{13, p p ~} 64-65$ and Nugent later indicates that the only requirement is that the outlay be financed by borrowing otherwise idle funds. ${ }^{2, p p ~}{ }^{180-181}$ His contention regarding capitalization is apparently designed to relate the purchase to the 'investment' concept and visualizes the consumer as charging these high cost items to successive periods piecemeal, similar to the depreciation methods a businessman employs.

Nugent realizes, however, that, as stated above, the only important requirement is that the financing of the investment must be accomplished so that a withdrawal in one area does not counterbalance the additional income funds introduced in another area. The basis for his capitalization stipulation, then, is essentially to show that consumer instalment sales credit has the same effect as business or governmental capital expenditures, financed by a debt which is retired in instalments. Consumers' durables are, therefore, the capital goods of the household. His conclusion that an expansion of consumer instalment sales credit represents a 'stimulating outlay' while a contraction represents a 'depressing withdrawal' is, therefore, logical and consistent.

Nugent then considers the possible compensatory movements in other sectors resulting from instalment sales credit outlays. A case can be made for some increase in business saving, which might be required because of expansion of consumer credit, to finance receivables. This is a small and diminishing influence on the stimulating effect of the consumer credit expansion, essentially because there is a tendency to balance these increased receivables with short-term bank loans, and consumer credit is being financed increasingly by banks. In addition, if this credit were used merely instead of withdrawing and repaying individual savings, these movements would have no significance except to reflect the decisions of the individuals. Nugent believes that such is not usually the case. Therefore, he concludes that compensatory influences in other sectors are relatively unim. portant, and the movements of consumer instalment sales credit balances may be treated as independent forces.

Having fitted consumer instalment sales credit into the Keynesian analysis, Nugent concludes that so long as the proper resources are not fully employed and are well distributed, qualitatively and geographically, any expansion of this credit will tend to induce some greater expansion of incomes and production to the extent indicated by the multiplier, while contraction of consumer instalment sales credit will, in a like manner, tend to produce multiple contractions of incomes and production. At full production and employment the classical position will hold true as a special case; an expansion of consumer instalment sales credit means increasing prices and a shift from producers' to consumers' goods. The use of macroanalysis has disclosed the interesting paradox that at the beginning of a recession period the wise decisions of individual debtors to get out of debt is inimical to the best interests of the economy as a whole.

\section{Haberler's explanation}

Haberler's work shows further consideration and examination of the effect of consumer instalment sales credit fluctuations on the economy. He considers several of Nugent's assumptions which the latter had not fully explored and other points which Nugent had touched upon only lightly. One of these concerned the money supply. Even under conditions of incomplete utilization of the factors of production, the supply of money must be sufficient so that other possible borrowers are not restricted, in order for consumer instalment sales credit to have its full stimulating effect. . $^{32}$ Another important question concerned the possibility that an increase in production in one industry due to expansion of consumer instalment sales credit will mean contraction in another. Much of the growth of the motor industry has been attributed to the availability of consumer credit, and the public transportation industry has suffered as a result. Finally, he indicated the need for further investigation of the question of consumers' assets: assuming instalment credit were not available, how might consumers apply them to the purchase of durables, and in budgeting for repayments of instalment loans, how do consumers assess their assets.

The money market appears to offer a very elastic supply of funds for consumer instalment sales credit. Financial intermediaries in this field usually have good credit ratings and are prime customers in obtaining funds from the banking system, and the commercial banks make the primary decisions regarding the availability of funds for their own consumer credit customers. (The activities of 'near banks' or 'quasi banks' (like hire purchase banks) have come to resemble those of commercial banks so 
closely that they are no longer considered as innocent financial intermediaries which merely channel savings into real investment, but in the Bank Act of 1965 came to be viewed as institutions which have appreciable monetary significance. Thus, no distinction is made between commercial banks and 'near banks' for purposes of monetary policy and banking legislation.) The possibility of the money supply being tightened sufficiently to make the banking system unable to meet the requirements of a rapidly expanding volume of consumer instalment sales credit, without crippling the entire economy, is open to question. It should be noted also that, since the interest costs of hire purchase credit is a negligible part of total operating expense, they (the banks) may be less restricted by tight money situations than other borrowers, and we may assume for general discussion that the supply is elastic. ${ }^{5 . p} 39$

Consumer instalment sales credit has undoubtedly stimulated long-run structural shifts in demand from nondurables and services to durables. The increase in national income resulting from the growth in durables production has often been offset to some extent, therefore, by the reduction in the older industry. The decline of the motion picture industry in the last decade or so, for example, must be attributed, at least in part, to the similar entertainment now offered in the comfort of one's living room through the medium of television. Thus we see that this decline is a countereffect in the economy which tends to offset the stimulating action of the hire purchase credit expansion related to the purchase of television sets. The effect gradually diminishes as the new industry matures and consumers buy bigger, better, and more expensive models of the durable to replace those initially acquired, while the older industry stabilizes at a new level.

The expenditures for motor cars have seriously affected the public transportation industries. Many consumers who formerly used the services of bus, train and other transportation companies have been able to substitute private car travel, when the means for purchasing this durable good was provided. Not only has relative income in the transportation industry itself been reduced, but in addition, the capital goods production associated with this sector may have sustained an accelerated reduction. ${ }^{5}$. pp $46-47$

The extent to which the latter effect occurs depends upon the rate of growth of the older industry at the time that the consumers' durable good enters into competition with it. If the older industry's demand for producers' capital equipment were small, due to its lack of expansion and failure to replace at the rate of depreciation, the total stimulus of the new industry's requirements would be felt. In contrast, if a still growing older industry were faced with such competition, its capital equipment would be sharply cut back, and this would tend to of fset the new industry's growth from the standpoint of national aggregate totals.

Haberler on the whole agrees with Nugent that consumers would not accumulate the cash for most durable goods they now purchase on credit, if credit were not available. This is a reflection of the psychological bias in consumers' actions toward forced repayment of dissaving, represented by consumer instalment loans, over voluntary saving. In addition, although consumer assets are often sufficient to cover the cost of high-priced durables, there is ample reason to believe that many who now do not feel it worthwhile to liquidate long-term assets in order to avoid the cost of short-term instalment loans for the purchase of goods would feel the same in the absence of credit facilities. For this reason and because many do not have excess savings or assets to use, the conclusion seems justified that a smaller volume of purchases of consumers' durables would result, in the absence or restriction of consumer instalment sales credit. Nor are assets usually considered a source of funds for repayments. Repayments generally are provided for by reducing consumption expenditures. Therefore, the stimulating effect of instalment sales credit on aggregate demand can be observed by noting to what extent new credits outweigh repayments; conversely, the effect is depressing when repayments out weigh new credits.

In the long run the indications are that the direct influence of this credit is stimulating in any event, since new credits increase consumer spending but repayments only partially decrease it - they are partially provided for by the saving component of disposable income. Haberler appears to be in agreement with Nugent's Keynesian conception of secondary and tertiary effects. He concludes that 'credit is an intensifying factor in business cycles - accentuating booms and deepening depressions . . . an amplifier of fluctuations set up by other forces'.S. p 134

The cycles in instalment credit itself are directly related to the fluctuating volume of retail sales. The cycle of consumers' durables sales can be great in amplitude because of the nature of durable goods. A durable good may be characterized as a bundle of services that become available, successively, over a certain period of time. If the stock of durable goods is built up too quickly because of innovation, new styling, or model change, rather than actual need, we have the expansion phase of a replacement cycle in operation. The contraction is as sure to come as the bill collector. ${ }^{15}$ Since the desire for these durables can be modified by economic considerations and psychological factors, their purchase can be spread over a longer period than originally contemplated, and the replacement cycle can be decelerated, just as in the case of producer goods purchases. A reduction of $25 \%$ in the demand for motor cars would conceivably cause the production of cars to drop temporarily very sharply to zero. $^{5, p 131}$ Thus consumer instalment sales credit makes for instability in the long run, because it induces consumers to apply more of their income and resources to the production and use of durable, rather than nondurable goods and services and durable goods have a built-in factor of instability.

\section{A dissenting opinion}

It is possible to discuss the effect of consumer instalment credit sociologically, psychologically, and economically as individual concepts, but Haberler had emphasized the need for considering all these frames of reference together as much as possible in order to develop the true picture. Cox ${ }^{16}$ has followed this approach and refutes Nugent's strong contention (supported by Haberler) that consumer instalment sales credit is an intensifying factor in business cycles. ${ }^{16} \mathrm{He}$ maintains that structural changes 
have taken place which have influenced previous cycles, but these are not in themselves cyclical. His case appears to be that the psychological and sociological attitudes toward consumer credit remain the same, regardless of business conditions, since he states that credit is available at any time, and regardless of the phase of the cycle, to any consumer who has a income that will enable him to show good prospects of paying his account ... Nothing in the nature of either durable goods or the instalment system requires consumers to concentrate their purchases in the boom periods of successive cycles'. ${ }^{16, p} \mathrm{p}^{423}$

Cox recognizes the problem of acceleration of derived demand due to the nature of durable goods, but he attributes this not to instalment credit but to structural changes brought about by new or changed products. In discussing this principle, he characterizes any increase in instability as the stock of durables grows as the price consumers must pay for the rapid buildup of their stock of durables, and not a detrimental characteristic of instalment buying. There are statements in Cox's book, however, which contradict this statement indicating his realization that consumer instalment sales credit is a powerful enough institution in the overall picture of our present economy to be named as the factor which allows consumers to build up a large stock of durable goods quickly. In the paragraph preceding the discussion above he says, 'Insofar as instalment buying enlarges the stock of durables consumers accumulate by facilitating their purchase, it of course contributes to increasing the area of instability in the economy'. ${ }^{16, \text { p }} 429$

The key to Cox's dilemma lies in this statement from the last paragraph of the same section: 'If instalment buying can be held responsible for intensifying the problem of adjustment as growth slows down, it also deserves credit for speeding up the acquisition of durables'. ${ }^{16, p} \mathrm{p}^{429}$ Having built up such a good case for the advantage of instalment buying from the consumer's standpoint, because it affords him earlier possession of high-priced durables, he cannot easily reject the institution for its shortcomings, nor can he in good conscience ignore them. 'To a consumer whose one life is ticking inexorably away, the benefits of earlier consumption may be well worth the cost of even a severe later adjustment'. ${ }^{16, p}{ }^{429}$ What is true for the individual consumer, however, does not apply in the aggregate.

\section{Concluslon}

Consumer hire purchase credit undoubtedly aids consumers in obtaining durable goods sooner and perhaps in a larger total amount than they would achieve otherwise. The concept of additional benefits to consumers of more leisure time and greater satisfactions is generally acceptable. The stimulating effect of consumer credit is felt in the accelerated derived demand resulting from the buildup of a stock of durables, and this, coupled with the deferable nature of the demand for durables, results in a potentially highly unstable condition. Although the effects of a growing demand for durables is often of the nature of structural change, such things as style change in an established durable goods industry can happen rapidly. The total picture approaches more closely Schumpeter's innovation theory of the business cycle than it does a secular trend.

This cyclical movement of the sales of consumers' durables may be in or out of phase with the cycle in general business. The application of the multiplier principle to the additional investment represented by a rise in consumer hire purchase credit could be recognized if the result could be isolated. Without an appropriate statistical analysis this is, however, impossible, since aggregate national income data cannot be related to the volume of consumer hire purchase credit.

\section{References}

1 HARDY, C.O. (Ed.) Consumer credit and its uses. Prentice Hall, New York, 1948. Ch. I.

2 NUGENT, R. Consumer credit and economic stability. Russell Sage Foundation, 1939.

3 HARRIS, R., TAYLOR, M., \& SELDON, A. Hire purchase in a free Society. Hutchinson, 1961.

4 VAN WAASDIJK, T. Hire purchase credit in South Africa: An economic survey. Witwatersrand University Press, Johannesburg, $1956 \mathrm{Ch}$. III.

5 HABERLER, G. Consumer instalment credit and economic fluctuations. National Bureau of Economic Research, 1942.

6 SELIGMAN, E.R.A. The economics of instalment selling. Harper \& Brothers, New York, 1927.

7 VAN WAASDIJK, T. Medium-term institutional credit in South Africa. Commerce Research Section, University of the Witwatersrand, Johannesburg, 1967.

8 South Africa, Report of the Committee of Inquiry into the Usury Act. RP 11/1968, Government Printers, December 1967.

9 South Africa, Press statement issued by the Deputy Minister of Economic Affairs. October 29, 1970.

10 PAXTON, D. Press statement issued by the President of the Association of Chambers of Commerce on tightening up of hire purchase conditions. October 29, 1970.

11 South Africa, Press statement issued by the Minister of Economic Affairs. November 26, 1970.

12 S.A. Reserve Bank, Quarterly Bulletin, March 1980.

13 MORS, W.P. Consumer credit theories: An historical and critical analysis. University of Chicago Press, Chicago, 1944.

14 KEYNES, J.M. The general theory of employment interest and money. Brace \& Co., Harcourt, 1936.

15 GALBRAITH, J.K. The affluent society. Houghton Mifflin Co., Boston, 1960. Ch. 14.

16 COX, R. The economics of instalment buying. The Ronald Press Co., 1948. Ch. 24. 